\title{
UNDERWATER OBSERVATIONS ON ESCALLOP (PECTEN MAXIMUS L.) BEDS
}

\author{
By R. H. Baird \\ Fisheries Experiment Station, Castle Bank, Conway, North Wales \\ and F. A. Gibson \\ Department of Agriculture, Fisheries Branch, Dublin
}

(Text-figs. I-5)

\section{INTRODUCTION}

In an age-frequency distribution plot of a biological population, it is axiomatic that there should be, in general, a preponderance of young. This expected distribution is not found when sampling some marine animals, notably lobsters and escallops. Many workers, including Priol (1930), Tang (I94I), Elmhirst (1945), Baird (1952), Fairbridge (1953), and Mason ${ }^{1}$ have noted the absence of young escallops (Pecten sp.) in the expected numbers in dredge hauls.

A dredge without teeth, lined with sprat netting, was used at Brixham in an attempt to catch the young escallops, but this dredge filled so quickly with sand, gravel and shell that very few escallops were caught, although those taken did have a generally lower size-range than the escallops caught with a standard toothed dredge. At Castletownbere (Co. Cork) a naturalist's dredge similarly failed to catch many escallops.

The relative scarcity of the young escallops may reasonably be explained in one of two ways:

(I) Settlement may occur in feeder beds, probably inshore, from which, upon reaching a certain size or age, the young escallops migrate back to the parent beds to effect the necessary recruitment.

(2) The young may be present on the beds, but for some reason are not caught.

The first explanation has been fairly widely held, but in some cases, notably in the English Channel beds off Newhaven (Baird, I952) very long migrations from inshore waters would be necessary. Moreover, recaptures of tagged escallops have never shown any appreciable evidence of migration (Gibson, 1953; Mason ${ }^{1}$ ). To investigate the second possibility it was decided that direct observations of the escallops on the beds by the use of diving apparatus would be necessary.

The commercial escallop beds in Berehaven Sound, between Bere Island and the mainland, County Cork, were chosen for the initial investigation

${ }^{1}$ J. Mason, Ph.D.Thesis, Liverpool University, 1953, 42 pp. 
because escallops were found there in depths ranging from 3 to $\mathrm{I} 4 \mathrm{~m}$ (IO-46 ft). The Sound is nearly 7 miles long and from one-half to three-quarters of a mile wide. The beds in the Sound had formed the basis for population studies during the preceding 4 years, and a series of tagging experiments had been made (Gibson, I953).

An exceptionally high proportion of o-group escallops had been taken during 2 days commercial fishing in December, 1949, at Castletownbere. Of 400 escallops dredged on this occasion 5I were o-group. This high proportion has not been noted since, and the percentage of o-group in commercial catches seldom exceeds $2 \%$, but the suggestion remained that the young were present.

It was later found desirable to continue the work at Port Erin, where escallops are found in depths ranging from $\mathrm{I} 7$ to $60 \mathrm{~m}$ (56-I98 ft.), although observations were limited to a maximum of $37 \mathrm{~m}$ ( $\mathrm{I} 20 \mathrm{ft}$.), and collection and dredging to a maximum of $26 \mathrm{~m}$ ( $85 \mathrm{ft}$.). Escallops on these beds had been studied by Tang (I94I) and Mason.

\section{EQUiPMENT AND Methods}

A Siebe Gorman Aqualung compressed air, self-contained, diving apparatus and a Dunlop underwater swimsuit and swim fins were used.

The standard Irish escallop dredge was used at Castletownbere. This dredge was $\mathrm{r} .68 \mathrm{~m}$ ( $5 \mathrm{ft} .6$ in.) wide, with a toothed blade. The teeth had an average gap of $8.0 \mathrm{~cm}$, were about $7.0 \mathrm{~cm}$ long, and entered the sand to a depth of $1 \cdot 0-2 \cdot 0 \mathrm{~cm}$. The dredge bag and belly were made of sisal netting, $6.5 \mathrm{~cm}$ between knots, hung square on the dredge frame. The dredge was towed from an $\mathrm{I} 8 \mathrm{ft}$. boat, without motor, winched by hand up to an anchor.

At Port Erin a standard I. $\mathrm{I} 7 \mathrm{~m}$ (4 ft.) dredge completely lined with shrimp netting was used. This dredge had a toothed blade, with a gap of $7.5 \mathrm{~cm}$ (3 in.) between the teeth, which projected $5 \mathrm{~cm}$ ( 2 in.) from the bar. The dredge was towed from a $25 \mathrm{ft}$. motor boat.

The sampling at Castletownbere was done in September I953. All the sampling was done within a radius of I mile ( $1600 \mathrm{~m}$ ) at depths ranging from 4 to $\mathrm{I} 4 \mathrm{~m}$ (I3-46 ft.). Escallops of all sizes were fairly easily seen at all depths in spite of being recessed in the sand and covered with a layer of silt. The overlap of the bottom valve was visible when the valves were closed, and the extruded tentacles were seen when the valves were open. All escallops seen while diving were collected. Consumption of air by a diver is much increased at greater depths, and owing to a shortage of compressed air approximately $70 \%$ of the collection by diving was done at the lesser depths; most of the dredging was done at the greater depths because of fouling by annual sea weeds in the shallower water. Thus a possible source of bias was introduced in the sampling; the results of this sampling appear in Fig. I. 
To determine whether the results obtained at Castletownbere resulted from the bias introduced by the distribution of sampling, a further investigation was undertaken at Port Erin, Isle of Man, in July 1955. The diving and dredging were done at random on a bed of escallops off Fleshwick Bay. This bed was approximately half a mile $(800 \mathrm{~m})$ square, in depths ranging from I 7 to $26 \mathrm{~m}$ (56-85 ft.). Although underwater visibility was exceptionally good the escallops were not so easily seen as at Castletownbere. This was probably due to the general reduction of light at the greater depths and to the nature of the bottom, which was of a much rougher and coarser texture than that at Castletownbere. Again all escallops seen were collected and measured. Diving was alternated with dredging, both, as far as possible, being done in the same area. The results of this sampling appear in Figs. 2 and 3 .



Fig. I. Age-frequency distribution of collected and dredged samples at Castletownbere. Above: dredged sample, roo escallops; below: collected sample, 30 escallops.

\section{MOVEMENT AND DisTRIBUTION}

The escallops normally lie recessed in the bottom in a self-formed depression, the flat valve roughly in the plane of the bottom. Recent swimmers lie unrecessed. The time that elapses after swimming before the recessing is done is not known and is probably very variable. The recessing, which has been observed in action only once, is performed by ejecting water downwards; this is accompanied by a rocking movement. A great deal of the disturbed silt resettles on the upper valve.

The amount of swimming by escallops was very variable but in all cases limited, and occurred most frequently among the smaller ones. In general, not more than $5 \%$ of escallops collected by diving swam on the approach of the diver, although on one occasion Io out of $\mathrm{I} 2$ escallops collected swam, but the swimming did not appear to be directional. An escallop could easily be caught whilst swimming. Having swum, and come to rest, no further swimming could be induced. Most frequently a closure of the valves occurred 
on the initial approach of the diver. Buddenbrock \& Möller-Racke (I953) have shown that the reaction of Pecten and Chlamys to moving objects depends upon the velocity of the object - a slow movement results in a stretching of the tentacles towards the object-while a more rapid movement results in a retraction of the tentacles and closure of the valves. In neither case does the capacity to swim appear to result in an escape reaction and this was confirmed during these observations. Smaller escallops tended to swim more frequently than the larger ones, but even so the very low proportion that were found unrecessed indicated that very little recent swimming had occurred on the grounds examined.

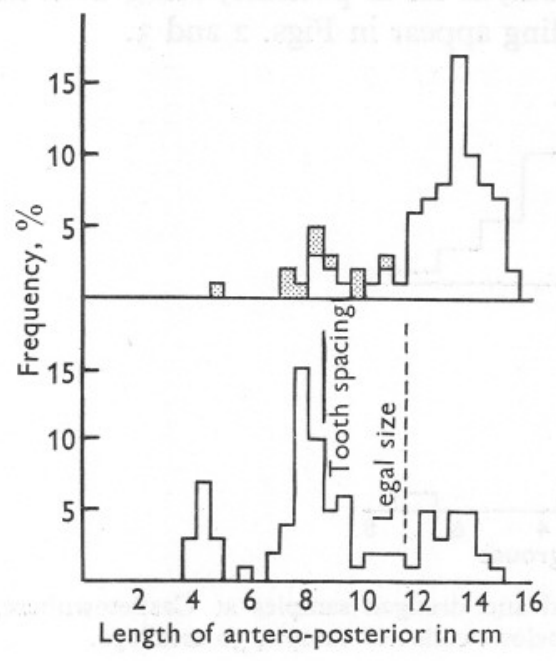

Fig. 2

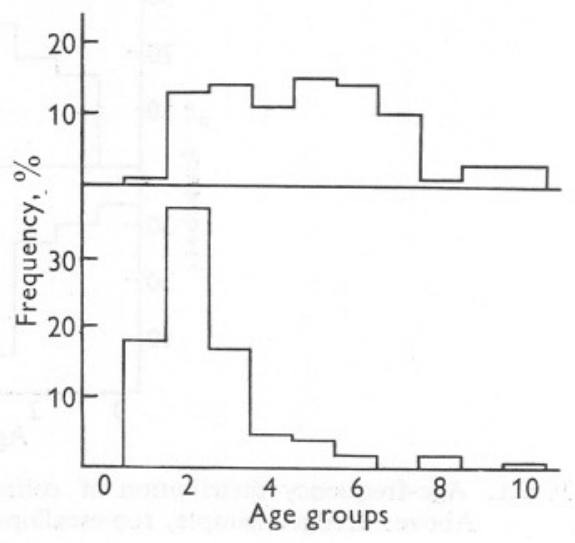

Fig. 3

Fig. 2. Size-frequency distribution of collected and dredged samples at Port Erin. Above: dredged sample, 85 escallops; below: collected sample, 86 escallops.

Fig. 3. Age-frequency distribution of collected and dredged samples at Port Erin. Above: dredged sample, 85 escallops; below: collected sample, 86 escallops.

In an attempt to determine whether any escape reactions occurred among the escallops the dredge was observed in action on the bottom at Castletownbere at a depth of $14 \mathrm{~m}$. In order to see what was happening at the teeth of the dredge it was necessary to look at the bottom immediately in front of the dredge from a height of only half a metre, and this resulted in a high apparent speed over the bottom when the dredge was being towed. Under these conditions it was very difficult to see escallops in the path of the dredge. In the course of the dredge observations only two escallops were positively seen in the path of the dredge, which was moving along in a series of long shallow leaps. Neither of these escallops was taken. On other occasions escallops 
were taken that were not seen. One I-group escallop was seen to escape outside the edge of the dredge and was captured by hand. The leaping movement of the dredge must result in a very low dredge efficiency.

The distribution of escallops on the beds was very patchy, estimated densities ranging from one per 2 sq. yd. $\left(1 \cdot 65 \mathrm{~m}^{2}\right)$ to one per $100 \mathrm{sq}$. yd. $\left(84 \mathrm{~m}^{2}\right)$. There was evidence of localized age grouping which would be heavily masked in dredge sampling. This patchiness appeared to be particularly evident among the lower age groups, though this may have been due to greater ease of identification of the age group of the younger escallops underwater. At Port Erin the 2-group, resulting from a good settlement year, was found almost everywhere but at varying densities.

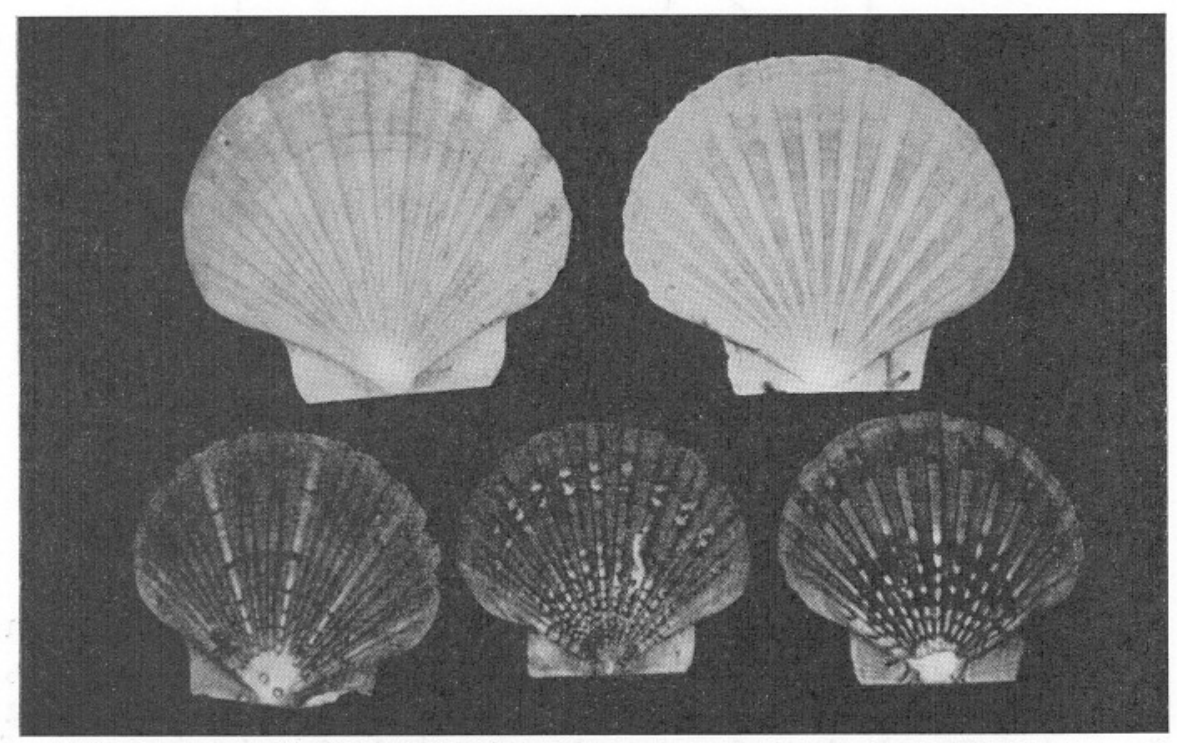

Fig. 4. Contrast in pigmentation of escallops from adjacent areas. The larger escallops are from deeper water and muddy bottom; the smaller from shallow water and gravel bottom.

At Castletownbere a wide range of sizes was found in shallow water on a gravel bottom, but in an area within $200 \mathrm{~m}$ ( $220 \mathrm{yd}$.) in deeper water on a muddy bottom, the few escallops found were all large. The pigmentation of the shallow water escallops was characteristic and different from that of the adjacent deeper water escallops (Fig. 4). There had obviously been no interchange of populations. A difference in pigmentation was also observed on escallops collected from gravel and muddy bottoms within a mile ( $1600 \mathrm{~m}$ ) of each other at Cornwall. The pigmentation in all cases was uniform from the earliest stages of shell growth, indicating that the escallops had been in the same local environment since settlement. 
At various intervals from April 1952 until September 1953, 719 escallops have been tagged at Castletownbere, of which $200(27 \cdot 8 \%)$ were recaptured by 15 April 1955 . Only two have been recaptured in places other than where they were released, and then only within I mile $(1600 \mathrm{~m})$. Neither can be regarded, therefore, as having made a significant migration. The periods at liberty, ranging from 2 days to 34 months, were adequate for migrations to have taken place, if such migrations are characteristic of escallops. Tagging experiments at Port Erin by Mason have shown a complete absence of migratory movement.

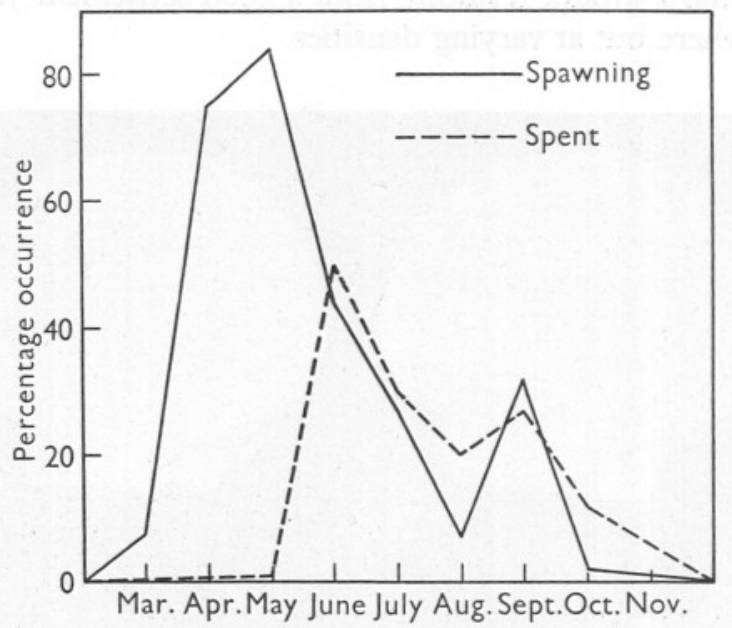

Fig. 5. Spawning and spent escallops in monthly samples.

At Castletownbere o-group escallops were collected in September. An analysis of the 1953 material has shown that spawning commenced in March, and reached a peak in May, fell away in July and August, and resurged during September (Fig. 5); the early spawned o-group had attained a size range of $2 \cdot 9-5.8 \mathrm{~cm}$ by September. None were embyssed. At Port Erin, Mason (1953) has shown that the major spawning occurs in the autumn - between 90 and $95 \%$ of escallops on these beds are autumn-spawned-and this will account for the absence of o-group in the collected sample at Port Erin in July (Fig. 3).

\section{Comparison of CATches by Diving and DREDGing}

It can be seen (Figs. I-3) that collection by diving yielded much smaller sizes and lower age-groups than collection by dredging. That this was not due to mesh selection in the bag of the dredge is manifest at Port Erin, where the bag was completely lined with shrimp netting that would retain all escallops. The teeth, which are the only other selective feature of the dredge, must be the effective selection agent. 
The shaded squares on the histogram of the dredged sample at Port Erin (Fig. 2) represent escallops caught when the dredge filled with gravel and stopped the boat, i.e. they were caught when the dredge was acting as a complete bottom sampler and the teeth were ineffective as a selecting agent. If the legal size limit ( $\mathrm{II} \cdot 5 \mathrm{~cm}$ or $4 \frac{1}{2}$ in.) is taken as an arbitrary line of size division, the actual distribution as indicated by diving shows $74.4 \%$ of the escallops on this bed to be below the legal size, while the dredge retained only $23.5 \%$ below this size. The teeth on the dredges, the length and spacing of which are not regulated, are therefore seen to constitute a highly effective saving gear.

Truly representative sampling of escallop beds is difficult. The low densities of escallops makes grab sampling impracticable. Dredges that effectively sample the whole size-range of the population have to have a considerable 'bite' because the escallops are recessed. They thus retain much of the bottom material and are effective for only a short distance. In consequence of the low densities at which escallops occur, such small catches are obtained under these conditions that sampling becomes extremely laborious.

Underwater photography and underwater television have been developed in recent years as methods of observing bottom animals. There are limitations to their use in assessing escallop populations. The area of the bottom observed is small and the escallops would not always be easily seen. The equipment required is relatively expensive. The advantages of the methods lie in their capacity to operate at greater depths and lower temperatures than is possible for a diver using self-contained breathing apparatus.

We would like to acknowledge, with thanks, the co-operation of the Director and staff of the Marine Biological Station at Port Erin in making boats and facilities at the laboratory available.

\section{SUMMARY}

Present methods of dredge sampling of escallop beds are unsatisfactory where all age-groups require to be studied. Selectivity by the dredge is continued above the point that might reasonably be expected from mesh size and tooth spacing, the latter being the primary selecting agent. A dredge without teeth and with a fine mesh bag fills with sand and bottom material within a short distance. As the mean density of escallops is low, even on good commercial beds, this results in very small catches.

Escallops of all age-groups are present together on the beds with a tendency towards very localized age grouping, which would not be apparent in dredge sampling. There is no evidence that migration from feeder beds occurs.

There is little apparent escape reaction; the limited reactions seen occurred most often among o- and I-group escallops. 
Dredge efficiency is low, the Irish dredge used being on the bottom for only a part of the time that it was moving, progression occurring in a series of long shallow leaps.

Conservation of stocks of escallops would be most effective if based on dredge-tooth spacing and size rather than on the size of mesh or rings forming the belly of the dredge.

\section{REFERENCES}

Batrd, R. H., 1952. The English Channel escallop beds. Fish. Nerws, No. 2064, p. 9.

BudDenbrock, W. V. \& MölleR-Racke, I., I953. Über den Lichtsinn von Pecten. Pubbl. Staz. zool. Napoli, Vol. 24, pp. 217-45.

Elmhirst, R., I945. Clam fishing in the Firth of Clyde. Trans. Buteshire nat. Hist. Soc., Vol. I3, pp. II3-I6.

FAIRBRIDGE, W. S., I953. A population study of the Tasmanian 'Commercial' Scallop, Notovola meridionalis Tate. Aust. F. Mar. Freshw. Res., Vol. 4, pp. I-40.

Grbson, F. A., I953. Notes on the tagging of the Escallop ( $P$. maximus L.) in Irish waters. F. Cons. int. Explor. Mer, Vol. 19, pp. 204-8.

Priol, M., 1930. La coquille St Jacques (Pecten maximus). Rev. Trav. Off. Pêch. marit., T. 3, pp. $143-73$.

TANG, Shin-Feng, I94I. The breeding of the escallop (Pecten maximus) with a note on the growth rate. Proc. Lpool biol. Soc., Vol. 54, pp. 9-28. 